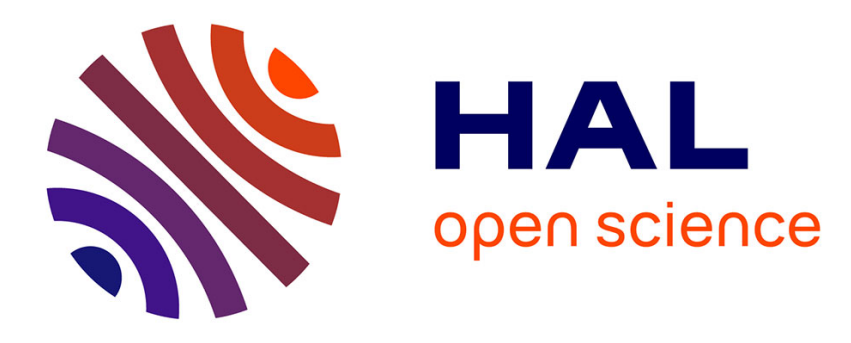

\title{
Macabre Short-Stories by Edgar Allan Poe and Roald Dahl
}

Florence Casulli

\section{To cite this version:}

Florence Casulli. Macabre Short-Stories by Edgar Allan Poe and Roald Dahl. Caietele Echinox, 2018, 35, pp.25-47. 10.24193/cechinox.2018.35.02 . hal-02441753

\section{HAL Id: hal-02441753 \\ https://univ-angers.hal.science/hal-02441753}

Submitted on 9 Oct 2020

HAL is a multi-disciplinary open access archive for the deposit and dissemination of scientific research documents, whether they are published or not. The documents may come from teaching and research institutions in France or abroad, or from public or private research centers.
L'archive ouverte pluridisciplinaire HAL, est destinée au dépôt et à la diffusion de documents scientifiques de niveau recherche, publiés ou non, émanant des établissements d'enseignement et de recherche français ou étrangers, des laboratoires publics ou privés. 


\section{Florence Casulli}

\section{Macobre Short-Stories}

\section{by Gdgar Allan Poc and Roald Dahl}

\begin{abstract}
Focusing on Edgar Allan Poe and Roald Dahl's short-stories, this paper's main framework aims at demonstrating that although it may not seem initially obvious, the works of the two authors share not only one, but many characteristics. Before writing his famous children's fiction, Roald Dahl established his reputation as a writer of deathly short stories with unexpected twists that may recall Poe's Gothic tales. Therefore Dahl, who has never been considered part of the Neo-Gothic stream, has nevertheless incorporated Neo-Gothic elements in his work. The first part of this paper will focus on the Gothic genre of the two authors (and its characteristics) as it appears to be their common playground. In the second part of this study, the theme of the tortured body will be treated and will attempt to highlight the idea that the body, in Poe's and Dahl's works, stands for an externalization of the narrators' tortured minds.
\end{abstract}

Keywords: Roald Dahl; Edgar Allan Poe; Gothic; Neo-Gothic; Short fiction; Charles Mauron; Psychocriticism; Trauma Narratives.

\section{FLORENCE CASULLI}

CIRPALL, University of Angers, France casulli.florence91@gmail.com

DOI: 10.24193/cechinox.2018.35.02
\Then Roald Dahl died in 1990, he $\checkmark$ was one of the most popular authors in the world. Although his oeuvre was dominated by children's classics such as James and the Giant Peach (1961) or Charlie and the Chocolate Factory (1984), he also was a prolific author of short fiction for adults. Even though his oeuvre has generally been praised, it has not aroused academic interest and has not been studied extensively. When reading Dahl's short stories, one can be bewildered by the many similarities they share with Edgar Allan Poe, an extensively-studied author. In his analysis of Dahl's story "The Landlady", Jacques Sohier effectively attributes the adjective "Poesque" 1 to one of the author's narrative aspects, underlining the special relationship between the two authors' works. Coherently, Dahl's stories earned him three "Edgar Allan Poe Awards" from the Mystery Writers of America in 1954, 1960 and $1980^{2}$.

The fact that Dahl won these awards highlights the special relationship between the two authors' worlds. In one of Dahl's biographies entitled Storyteller - The Life of Roald Dabl (2010) by Donald Sturrock, the author states that Roald Dahl is commonly nicknamed the "Master of the Macabre" 
since his sinister and surprising tales continue to entertain, amuse or shock generations of readers even today, just like Poe's tales do. Even though the connection between Poe's and Dahl's tales has never been closely examined, Sturrock underlines the fact that Dahl "developed a fascination with Victorian ghost stories and Gothic fantasy, which he was to maintain for the rest of his life"4. Therefore this paper's main framework aims at demonstrating that Poe's tales may have indeed influenced Dahl's short stories for adults which, therefore, can be seen as $\mathrm{Neo-Gothic} \mathrm{stories.}$

Although Roald Dahl is never listed among other Gothic or Neo-Gothic writers, his works (even his children's books) present many Gothic characteristics and, in "A Tour of the Cannibal Quarters: Industrial Fantasies and Carnivorous Appetites in Roald Dahl's Fiction" (2010), Lorna Piatti-Farnel naturally argues that in Dahl's fiction; "there is to be found a home for the Gothic; a dwelling site of the psychologically disturbed"5. This statement may indeed be validated thanks to Marie Mulvey-Roberts' statement in The Handbook to Gothic Literature (1998) (a wide and eclectic range of scholarship essays devoted to Gothic literature) which asserts that "[in] the 1960s (...), the twentieth century see a burgeoning of Gothic fiction comparable to the one that began in the 1790s and swept through the first three decades of the nineteenth century $(. . .)^{6}$. The Gothic genre was thus Poe's favorite and it probably has also inspired Dahl's Neo-Gothic style.

One important aspect of Poe's Gothic and Dahl's Neo-Gothic short stories lies in the authors' ability to describe the body and, more precisely, the gruesomeness of the latter when mutilated. Poe's tales deal with murderers deteriorating their victim's body, concealing it or preserving it after death. Bernard Brugière in Les figures du corps dans la littérature et la peinture anglaises et américaines de la Renaissance à nos jours (1991) indeed affirms that mutilated bodies abound in Poe's fiction: "Poe's most well-known representation of the body is the dismembered body: the Cartesian body-machine that is destroyed to the last bolt" . As far as Dahl's short stories are concerned, some of the characters' bodies are also mistreated and very much neglected. However, the violence done to the bodies in both authors' fiction may be conceived as allegorical because, as Ailsa Cox and Christine Lorre-Johnston examine in The Mind's Eye: Alice Munro's Dance of the Happy Shades (2015): the Gothic genre mainly "aimed at exploring symbolically, through tales of mystery and horror, psychological states related to madness, fear, or cruelty [...]"8. It will be one of this study's intentions to show that behind the various mutilations of the bodies in their short stories lies the following question: what is the relation of the body to what lies inside of it, to that which no one can see (the soul/ the mind)? Indeed, considering Brugière's theory that "displaying 'the body' is supposing "what is not the body"', both authors seem to be concerned with the mind, and more specifically the externalization of the latter onto the body.

In order to demonstrate Poe's influence on Dahl's works, this paper will be based on a selection of the writers' short stories, namely "The Black Cat", "The Cask of Amontillado", "The Oval Portrait" and "The Tell-Tale Heart" by Poe and "The Landlady", "The Way Up To Heaven", 
"Skin" and "William and Mary" by Dahl. These short stories seem to be appropriate as they may all be considered Gothic and Neo-Gothic thanks to their gloomy atmosphere, the themes they have in common such as death or madness but more specifically, this selection of texts is motivated by the authors' apparent will to investigate the close connection between the human body and the mind through these tales.

The first part of this paper will therefore focus on the Gothic genre of the two authors (and its characteristics) as it appears to be their common playground. Then, in the second part of this study, the theme of the tortured body will be treated and will attempt to highlight the fact that the body, in Poe's and Dahl's works, stands for an externalization of the narrators' tortured minds. Finally, one conceptual tool will be used as it allows readers to move towards a better understanding of the authors' texts. Indeed, mainly focusing on Charles Mauron's method called "Psychocriticism", which attempts to show that an author's traumatic biographical past may be unconsciously reflected in his fiction, the last part of this essay will endeavor to show that both authors undeniably seem obsessed with this theme of the mutilated body and that, this obsession may effectively be traced back to Poe's and Dahl's harsh lives, making their fiction "trauma narratives".

\section{Poe's Gothic and Dahl's Neo-Gothic Qualities}

$\mathrm{A}_{\text {aspect of a Gothic story is to be found }}^{\text {sit is usually acknowledged, the major }}$ in the setting and more generally the atmosphere of a story. John Mullan, a Professor of English at University College London and a specialist in eighteenth-century literature, states, in an online article entitled "The Origins of the Gothic", that Gothic locations often feature "strange or frightening old buildings" ${ }^{10}$ because in Gothic architecture itself (which was seen as barbaric and which did not follow the classical ideals of simplicity, unity, and symmetry) high towers, vaults, arches, flying buttresses, or elements like gargoyles prevailed in churches, castles, and monasteries. Consequently, in Gothic literature, the action often takes place in that kind of landscape. Old and ruined castles, abbeys or houses that seem abandoned and filled with dark secret passages or rooms are commonly known as being Gothic locations.

In Poe's "The Oval Portrait", the unnamed narrator sojourns within a dark castle located in a desolate landscape: "The château [...] had been temporarily and very lately abandoned" 11 and the castle is filled with "tapestries", "trophies" and "paintings" ${ }^{2}$. Moreover, in the opening paragraph, the narrator evokes one of the pioneers of the Gothic genre: "Mrs. Radcliff"13, to refer to the "gloomy"14 atmosphere of the desolated chateau. In "The Cask of Amontillado", the story takes place in a claustrophobic context: the "vaults"15 of the narrator's "palazzo"16. This location is undeniably a Gothic one, according to Frederick S. Frank who states that "The primal Gothic journey is the journey through underground passageways to the horror of horrors"17 in his bibliographical guide devoted to American Gothic writers and various modes of Gothicism from the late eighteenth century to the late twentieth century entitled Through The Pale Door: A Guide to and Through the American Gothic 
(1990). Because this kind of setting is dark and isolated, the atmosphere of the Gothic genre "is one of gloom and mystery"

Dahl's "The Way Up to Heaven" may be a Gothic location as the house in which the characters live looks like a castle: it is "a large six-story house" 19 and they have "four servants" 20 but his other stories do not take place in castles or in secret underground passageways. Though Dahl does not set his stories in Gothic landscapes, the atmosphere of his stories is equally gloomy and mysterious, and that is one of the reasons why his work might be considered Neo-Gothic. The atmosphere of each story is indeed dreary and obscure and thus recalls the Gothic genre. William, in "William and Mary", even uses the word "gloomy" to describe his hospital bedroom and the atmosphere of "The Way Up To Heaven" is depicted as being "peculiarly oppressive" 22 , highlighting the Gothic atmosphere of the stories.

Poe's gloomy atmosphere is mostly conveyed thanks to the dark setting of his stories, but also thanks to the emotions and feelings the writer seems willing to generate in the reader's mind such as fear or disconcertment. For instance, when reading "The Cask of Amontillado", a reader may be scared because of the places described in the tale and the dreadful action Montresor is performing to take revenge. And, when reading "The Black Cat", a reader may easily be disconcerted at the end of the story when the narrator ends up killing his wife because of the hatred he had towards a cat. In other words, the atmosphere of Poe's stories becomes gloomy and oppressive because of the tales' plot, the emotions they convey and the kind of settings in which they take place.
Similarly, Dahl's gloomy atmosphere is often created because the stories he unfolds relate classic Gothic plots with typical Gothic characters. Indeed, Marie Mulvey-Roberts argues that, in a Gothic story, the plot often features characters such as "a swooning heroine replete with sensibility, and a tyrannical villain" 23 and that characteristic is to be found in Dahl's stories. For instance "both ['The Way Up To Heaven' and 'William and Mary'] are about tyrannical husbands, and both give memorable victories to the downtrodden wives" ${ }^{24}$. Because the plots of Dahl's stories are imbued with tyranny and revenge, the atmosphere of his stories is bleak and evokes the common Gothic atmosphere. In other words, even though the settings of Poe's and Dahl's stories differ, their atmospheres are equally Gothic.

There is nonetheless a particular setting that seems to bring together Dahl's and Poe's tales and that is the domestic one. Indeed, in all the short stories under study, the actions take place in a domestic setting. Although Poe sets his actions in mansions, castles or underground places, he also puts his characters in their familiar environment. For instance, the action in "The Black Cat" mostly takes place in the narrator's house. In "The Tell-Tale Heart", the narrator is also in an environment he is familiar with: although the reader does not know exactly his role, it may be assumed that the narrator is the old man's caregiver who lives with him. Finally, Montresor in "The Cask of Amontillado" ventures in his own vaults. Like Poe, Dahl, with the exception of "Skin", which takes place in "picture gallery" 25 , places his characters in very domestic settings: the action of "The Landlady" takes place in a Bed and 
Breakfast; in "William and Mary", Mary reads her husband's letter at home; in "The Way Up to Heaven", the characters are mostly observed in their house. Therefore, it may be assumed that Poe and Dahl use the familiar, the domestic to create a specific atmosphere: an uncanny one.

Although the term "uncanny" ("das Unheimlich") was coined after Poe's death by Freud in a 1919 essay by the same title, Poe's tales feature the familiar as strange. In this regard, like Dahl's stories, his tales can be considered as uncanny. Ailsa Cox and Christine Lorre-Johnston in The Mind's Eye define the uncanny in Alice Munro's short stories as follows:

[Freud] defines the uncanny as 'that class of the terrifying which leads back to something long known to us, once very familiar.' $\mathrm{He}$ analyzes the origin of this terror by going back to the root adjective 'heimlich' and observing that it is ambiguous: it can mean either 'belonging to the house, not strange, familiar, tame, intimate, comfortable, homely, etc.' or 'concealed, kept from sight, so that others do not get to know about it, withheld from others.' Its opposite, unheimlich, means 'uneasy, eerie, bloodcurdling. ${ }^{26}$

In other words, in uncanny phenomena, the familiar becomes so unfamiliar that it "provokes terror, anxiety and fear [and] it generally refers to everything that provokes fear" ${ }^{27}$.

The domestic, because it is familiar, is thus an appropriate place for the uncanny to happen. In all the stories this essay examines, there is something uncanny. The authors, especially Dahl, emphasize this idea thanks to the vocabulary they choose. In Dahl's short stories, the lexical field of the uncanny, of the strange, overflows. For instance, a "queer" 28 and "peculiar" ${ }^{29}$ thing happens to Billy Weaver when he finds a place to stay and when he is strangely attracted to a seemingly nice landlady. Jacques Sohier, in his essay about the uncanny in Dahl's story entitled "Metamorphoses of the Uncanny in the Short-Story 'The Landlady' by Roald Dahl" argues that this moment is indeed uncanny:

Interestingly, Roald Dahl's short-story gives much textual space to the moment when the main character experiences the moment of the uncanny. This moment occurs when hesitation is at work and induces a strange response from the character, as if a powerful demonic force had him in its grip. $^{30}$

Moreover when Mary discovers her husband's body, words like "queer sensation", "unusual" or "intriguing" ${ }^{1}$ are also present in the text, underlining the uncanny quality of Dahl's writing.

Besides being exemplified by the wording, the uncanny feeling is apparent in many different scenes of the stories, whether Poe's or Dahl's. Both "The TellTale Heart" and "William and Mary" are haunted by the uncanny presence of an evil eye. Indeed, the narrator of Poe's tale is haunted by an eye and commits murder for the only reason that this eye "resembled that of a vulture"32. Mary in Dahl's short story is also haunted by an eye: her husband's. When he was alive, she already felt observed by his "pair of eyes" ${ }^{33}$ and now 
that he is dead she still feels the uncanny presence of his eyes: "All her life they had been watching her. And even now, after a week alone in the house, she sometimes had an uneasy feeling that they were still there, following her around, staring at her from doorways, from empty chairs, through a window at night" 34 .

In "The Black Cat" and "The Landlady", the uncanny atmosphere of the stories is mostly underlined thanks to the presence of animals. Indeed, in both stories the animals appear as uncanny as they haunt the characters. In "The Black Cat", what leads the protagonist to kill his wife is indeed the cat and the "hatred" 35 he feels towards it. Moreover the supernatural dimension of the animal underlines its uncanny quality. Black cats are commonly considered bad luck and they are symbols of evil because they have always been associated with witches. The narrator's wife is aware of that when she refers to them as "witches in disguise" 36 . The cat's name, "Pluto" ${ }^{37}$, also reminds the reader of the ruler of the underworld in Greek mythology. The underworld is supposed to be a dark, mysterious, enigmatic and faraway place. Undeniably, the cat represents evil and becomes unfamiliar. In "The Landlady”, the landlady herself is an uncanny figure because "the fact that she performs taxidermy not only on her pets but also on unwary young men, makes her into an uncanny woman, a figure of death, a representation of the deathdrive" ${ }^{38}$. The uncanny also manifests itself when Billy understands that the animals in the living room are stuffed: “'That parrot,' he said at last. 'You know something? It had me completely fooled when I first saw it through the window from the street. I could have sworn it was alive"'39. In both stories, the animals that are commonly considered as familiar become so unfamiliar that fear appears and the atmosphere becomes gloomy.

The uncanny also appears in "The Oval Portrait" and "Skin". Both stories deal with a very specific artistic exercise: the portrait. And in both stories, the fact that the artists manage to create perfect and life-like works of art is uncanny. The impression of life likeness is so real that the works of art in each story seem to become "quite alive" 40 and it disturbs both the narrators and the reader: "Least of all, could it have been that my fancy, shaken from its half slumber, had mistaken the head for that of a living person" ${ }^{41}$. Moreover, the life likeness of the portraits is also closely linked to death, highlighting its uncanny dimension. In "The Oval Portrait", the portrait is that of a "young girl just ripening into adulthood" 42 who dies as the painting is completed and in "Skin", the tattooist "falls into the hands of a mysterious, soft-spoken art dealer [who] promised a life of pleasure in exchange for the skin upon his back after he has died"43.

As Freud suggests, the presence of death is, in itself, uncanny: "Everything that is related to death, corpses, the return of the dead, spirits or spectres appear as highly uncanny to many people" ${ }^{44}$. Death may indeed be considered as uncanny because it is a part of human experience but it has always been a cause of preoccupation and fear. Because Poe's and Dahl's fictions "describe the intense emotions produced by objects of fear, whether they be uncanny or sublime, repulsive or threatening", they are horror fictions ${ }^{45}$ and what prevails in horror fiction is generally death. Both authors seem concerned about death and 
murders, mutilations or deconstruction of the body are common in their works. As Mulvey-Roberts suggests, representations of death in Gothic literature are frequent and "resonant because they touch on torture, murder and a transgressive desire for destruction" ${ }^{46}$ and they abound in Poe's and Dahl's stories.

\section{Tortured Bodies: Tortured Minds}

Tn The Cambridge Introduction to Edgar Allan Poe (2008) Benjamin F. Fisher draws attention to the fact that Poe is generally known and remembered for being a writer who used the Gothic genre to show that he was very much concerned about psychology: "Poe's creative writings are consequently peopled by characters whose emotions are fragile. (...) Poe undeniably created terror that was rooted in the soul, employing strategies adapted from the Gothic tradition to convey that terror" ${ }^{\prime 37}$. Roald Dahl also seems to be interested in psychology as his short stories are praised for being "creepy short stories, exploring human vices and follies"

Poe and Dahl were aware of the power of Gothic literature: they both realized that Gothicism was eminently compatible with psychological plausibility in literature. In order to deal with the psychological inside of their characters, they used an outside material: the body and its representations. It will now be argued that according to Poe and Dahl, a mutilated body is the medium through which a damaged psyche expresses itself. Both authors' achievement is that they describe by Gothic means states of consciousness that picture the distress and fragility 'of a human being. By representing mutilated bodies, the authors seem preoccupied with questions of identity conceived in corporeal terms because they know that the body is an essential tool for the self. However, instead of expressing themselves only through their own bodies, the characters in Poe's and Dahl's writings also favor the bodies of others to do so: they are not completely self-destructive and they use other bodies to express themselves.

One of the most striking examples of a body being tortured is to be found in the theme the authors have in common: live burials. This motif is exposed in two short stories, namely Poe's "The Cask of Amontillado" and Dahl's "The Way Up to Heaven". Besides sharing this motif, these short stories also share their major theme: revenge. According to Fisher, Poe's concern about live burials was very much motivated by a desire to frighten his readers because of the fear this kind of death inspired during the nineteenth century:

The sensational aspects of premature burial caused very real uneasiness in actual life; when embalming was not mandatory one could, for example, enter a death-like trance and actually be interred as if dead. There are newspaper accounts from as late as the 1920s that address the topic. So Poe wrote with knowledge of very real possibilities when he composed live burial situations. ${ }^{49}$

This fear of live burial was in Poe's time an actual fear and he wrote about it because he knew it would undoubtedly affect his readers. Dahl also exploited the theme of live burial in his story because he was equally aware of its sensational form as 
Freud reported it as being one of the most common phobias ${ }^{50}$.

Poe and Dahl's aim is to demonstrate their protagonists' identity crises through their similar choice of burying their opponents alive. Right from the start of Poe's and Dahl's stories, the reader is aware that the stories may be concerned with revenge because the characters have both been wronged. The opening line of "The Cask of Amontillado" is imbued with Montresor's revengeful tone: "The thousand injuries of Fortunato I had borne as I best could; but when he ventured upon insult, I vowed revenge" ${ }^{\text {" } 1}$. Even though an insult may be an insufficient motive to seek revenge, it really matters to Montresor who just wants to make his enemy pay. This motif of revenge is also highlighted by his family's motto "Nemo me impune lacessit" ${ }^{52}$ which means "no on provokes me with impunity" 53 . Because Montresor establishes a hierarchy in the severity of Fortunato's crimes that does not correspond to the severity of the punishment Montresor is going to inflict on him, there is a discrepancy that leads the reader to question Montresor's sanity. Moreover, in the opening line, the word "thousand" ${ }^{4}$ obviously is an exaggeration that suggests that Montresor feels persecuted and may be a victim of paranoia.

In Dahl's "The Way Up to Heaven", the reader is also introduced to a character whose sanity may be put into question because she has "an almost pathological fear" 55 of lateness. However, her sanity is quickly restored when the reader understands that this is her only obsession: "In other respects, she was not a particularly nervous woman" ${ }^{16}$. Despite this obsession, Mrs Foster appears as quite a lovely woman, who, although she has been a good and loving wife, has never been rewarded by her insensitive husband who may have been torturing her:

For over thirty years, she had served him loyally and well. There was no doubt about this. Even she, a very modest woman, was aware of it, although she had for years refused to let herself believe that $\mathrm{Mr}$ Foster would ever consciously torment her, there had been times recently when she had caught herself beginning to wonder. ${ }^{57}$

This possible torture (which will later on be proven) provokes the reader's empathy for Mrs Foster who, contrary to her husband, appears as a likable character. This dual relationship between Mrs Foster and her husband evokes one of the most important notions in Gothic literature: the notion of the "damsel in distress". Portrayed as feeble and powerless, the damsel in distress is a chief character of Gothic literature who "is pursued (...) by [a] villain figure [and who] may suffer imprisonment and cruelty at the hands of her pursuer" ${ }^{58}$. In Dahl's story, this Gothic character is embodied by Mrs Foster who is a submissive woman and who has been "disciplined" 59 by her husband. Mrs Foster's unhappiness is thus emphasized by the use of the Gothic theme of the damsel in distress which encourages the reader to feel sympathy for her.

In Edgar Allan Poe: A Phenomenological View (1973), David Halliburton argues that live burial is one of the most terrifying deaths one can endure because "the chief source of terror in premature burial (...) is consciousness" ${ }^{60}$. Thus it is a way for the protagonists to make the antagonists 
suffer. Because Fortunato has offended Montresor and Mr Foster has tormented his wife, choosing live burials seems appropriate in both cases. Because their victims are conscious when buried, "the idea of punishment" ${ }^{61}$ is highly relevant as the murderers want to punish their tormentors for neglecting them. Poe and Dahl aim at showing the impact an abused mind can have towards a body.

Another way of torturing the body in the tales under consideration is dismemberment. According to The Free Dictionary Online, to "dismember" literally means "to cut, tear, or pull off the limbs of" but it also means "to divide into pieces" ${ }^{2}$. In Poe's "The Tell-Tale Heart", the method of mutilating the body consists in a dismemberment as the victim's legs and arms are cut off from the old man's body: "I cut off the head and the arms and the legs" ${ }^{\prime 3}$. In Dahl's "William and Mary", William's body is also surgically dismembered given the fact that his body is completely cut into pieces because it is "useless" 64 and the only organs left are his brain and one of his eyes:

'So the next problem would be to remove your brain, intact and undamaged, from your dead body. The body is useless. In fact it has already started to decay. The skull and the face are also useless. They are both encumbrances and I don't want them around. All I want is the brain, the clean beautiful brain, alive and perfect'. ${ }^{65}$

Poe seems aware of a duality in man's nature when he for instance gives his definition of perverseness in "The Black Cat". According to him, everyone has a good and a bad side and sometimes, one side takes control over the other: the narrator of "The Black Cat", for instance, claims that the bad side of his personality has taken control when hurting the cat and he says: "The fury of a demon instantly possessed me. I knew myself no longer. My original soul seemed, at once, to take its flight from my body $[\ldots] "]^{\prime 66}$. And by using this Gothic motif of the Doppelgänger, Poe's and Dahl's aim is to highlight their main concern: self-destruction. Indeed, in the stories, both protagonists have a double and are, in a way, the same person. Many critics have seen in Poe's tale, a possible uncanny identification of the murderer to his victim:

Similar sensory details connect the two men. The vulture eye which the subject casts upon the narrator is duplicated in 'the single thin ray' $\ldots$ of the lantern that falls upon his own eye; like the unshuttered lantern, it is always one eye that is mentioned, never two. One man hears the creaking of the lantern hinge, the other the slipping of a finger upon the fastening. Both lie awake at midnight 'hearkening to the death-watches in the wall'... The loud yell of the murderer is echoed in the old man's shriek, which the narrator, as though with increasing clairvoyance, later tells the police was his own. Most of all the identity is implied in the key psychological occurrence in the story—the madman's mistaking his own heartbeat for that of his victim, both before and after the murder. ${ }^{67}$

These details indeed seem to bring the two men (who nonetheless appear as being completely different) together and Halliburton furthermore suggests that the 
most crucial event in the story, that is to say the burial, also functions as a reminder of the inseparability of the two men: "By this burial the victimizer attempts to architecturalize his relationship to the victim, to demonstrate with the solidity of matter that victimizer and victim are separate, when in fact they are inseparable"68.

This process of identification between two characters may also be noticed in Dahl's "William and Mary". Before the reader is introduced to Landy, William's personality is depicted thanks to the focalization on his wife's thoughts. For instance, the reader understands that William had never been a good and lovely husband and that he had always controlled his wife: when Mary imagines what is written in his letter, she hopes it is "a sort of love letter, a lovely warm note of thanks" 69 , but what she finds is "fifteen or twenty sheets of lined white paper, folded over once and held together at the top left-hand corner by a clip"70 written in "a neat businesslike manner [which don't] even begin in the nice way a letter should" 71 . The reader also discovers that she has been a submissive and loyal wife who has been "ironing a million shirts and cooking a million meals and making a million beds"72 for the last thirty years of her life. But William had never thanked her; instead, he was an unemotional strict man who just wanted to be obeyed: "It was bound to be formal - stiff and formal. The man was incapable of acting otherwise. He had never done anything informal in his life"73. William's strict and coldhearted personality is echoed by Landy's personality, who just like William, appears as an uncompassionate controlling man.

Indeed, Landy is also an insensitive man. For instance, he uncarefully enters
William's room: "he didn't creep in on his toes, sheepish and embarrassed, not knowing what to say, like all my other visitors" ${ }^{\text {" }}$. Landy stands out from the other visitors because, even though William is dying, he does not care and is a straightforward man. Moreover, he keeps on reminding William that he is going to die soon: "you're going to be dead", "You're going to expire"75. In other words, he is apathetic despite the tragic situation. Landy can thus be seen as William's double: his relation to William is a brutal and emotionless one just like William's relationship to Mary, in which she did not receive the love and affection she felt she deserved. Landy also addresses William childishly by calling him "my boy"76 and giving him orders "Don't interrupt, William. Let me finish" " Landy's strict behavior recalls William's behavior towards Mary which is emphasized at the end of his letter when William gives instructions to Mary:

PS. Be good when I am gone, and always remember that it is harder to be a widow than a wife. Do not drink cocktails. Do not waste money. Do not smoke cigarettes. Do not eat pastry. Do not use lipstick. Do not buy a television apparatus. Keep my rose beds and my rockery well weeded in the summers. And incidentally I suggest that you have the telephone disconnected now that I shall have no further use for it. ${ }^{78}$

The anaphora of "Do not" moreover creates an overwhelming effect that may also remind the reader of Landy's insistence when he tried to convince William to do the surgery after his death.

Furthermore, another parallel may be found in William and Landy's hubris, 
that is to say their "violent passion of pride [which] more fundamentally shows a refusal of the human condition by denying the limit between the mortals' world and the immortals"'79. William's hubris lies in the fact that he used to rule his wife's life and acted like a God towards her, dictating to her the way she should behave. For instance, even though Mary wanted to smoke, he would not let her do it and because "he had also disapproved of children"80, "they had never had any of them" ${ }^{\text {" }}$. William undoubtedly ruled his wife's life, disregarding her desires. Landy is a scientist, a rational man, who sees himself as having the power of William's afterlife in his hands: "Personally I don't believe that after you're dead, you'll ever hear of yourself again-unless [...] you have the sense to put yourself into my hands" ${ }^{\prime \prime 2}$. William even evokes Landy's look that seems to say “Only I can save you" ${ }^{3}$. In other words, Landy places himself as a kind of God to William and it accordingly shows his hubris.

Because the old man in Poe's tales appears as the narrator's doppelgänger and Landy in Dahl's as William's double, it might be argued that the dismemberment against their double is used against a part of their own person. Indeed, when Poe's narrator kills the old man and dismembers him, one can assume that, in fact, "he [seeks] to kill a part of himself" 84 and thus the old man can be seen as his murderer's doppelgänger.

Just like the old man in Poe's tale, William's body is going to be mutilated by the neuro-surgeon, Landy, who dismembers it. The surgical act is fully explained to William from page 24 to 33 but it is also conveyed metaphorically when William eats a grape and takes three seeds out of his mouth and places them on a plate: "I was lying on my back eating a grape. Delicious it was, and there were three little seeds in it which I took out of my mouth and placed on the edge of the plate" 85 . Even though this image seems innocent, it may foreshadow what is going to happen to William after he dies: he will, just like the grape, be dismembered and parts of his body will be placed on an operating table. As a consequence, by performing a surgical act that aims at dismembering William's body, it may be assumed that Landy's own scattered identity is revealed. Because the two men are seen as the same person, Landy's dismemberment of William's body may imply that Landy is in fact mutilating his own self. In "The Tell-Tale Heart" and "William and Mary", both authors seem once again willing to expose the effects an unbalanced self can have on a body through mutilation. In both stories, the protagonists have a doppelgänger and these doubles stand for a part of the protagonists' identities. Because these doppelgängers are going to be murdered and dismembered, the protagonists unconsciously kill a part of their own selves and the stories' main concern is therefore self-destruction.

Mutilating and destroying a part of one self may also actually be the central concern of another tale: "The Black Cat" by Poe. Indeed, what leads to this interpretation lies in Poe's ability to draw parallels between the cat, the narrator's wife and the narrator himself. First cats are generally associated with women's attributes. In her psychoanalytical study of Poe's tales entitled Edgar Poe: Sa Vie, Son Oeuvre (1933), Marie Bonaparte draws attention to the general interrelationship between a woman and a cat by referring to the popular belief 
that the cat is the symbol of the female sex organ:

[...] The cat is a common symbol for female genitals. Besides the cat and the female sex organ have the hairs in common: both have dense, hot and irritating hairs-a woman has got a cat where the man has got a penis. Moreover, the whole appearance of a cat is feminine: it is elegant but also unreliable as one can be easily mislead by its movements, especially when its claw pops up from its delicate paw. ${ }^{86}$

Even though this statement may appear outdated, it is relevant in the context of this research as it reinforces the idea that cats are generally associated with women and represent femininity in general.

The relationship between the cat and women is also made obvious in Poe's tale thanks to the many common features the cat and narrator's wife share. Through a series of humanized details that can be applied to a docile and affectionate wife but also to a cat, the cat may be seen as "a surrogate of his (i.e the narrator's) wife" ${ }^{87}$. The most striking connection between the narrator's wife and the cat is the fact that both characters are victims of the narrator's violent behavior. The wife is for instance pictured as a wife who is mistreated by her husband: "I suffered myself to use intemperate language to my wife. At length, I even offered her personal violence" ${ }^{88}$. Similarly, the first cat, Pluto, is also hurt by the narrator before being killed: “(...) even Pluto began to experience the effects of my ill temper" ${ }^{\prime 89}$. The cat is thus representative of the narrator's wife but more generally of women, and it thus stands for femininity.
Furthermore, the narrator is himself associated with his wife and women in general, because of the features they have in common. The narrator underlines his own feminine traits such as "tenderness of heart," and "unselfish and self-sacrificing" ${ }^{90}$ love for his pets. This love for pets is also shared by his wife, underlining his feminine traits:

I was especially fond of animals (...) I married early, and was happy to find in my wife a disposition not uncongenial with my own. Observing my partiality for domestic pets, she lost no opportunity of procuring those of the most agreeable kind. We had birds, gold-fish, a fine dog, rabbits, a small monkey, and a cat..$^{91}$

Consequently, because the narrator is also associated with his wife, who is herself associated with the cat, he is, by proxy associated with the cat who represents femininity. The cat may thus represent the narrator's feminine traits and that is the reason why he thinks he has to kill it. Kevin Hayes in The Cambridge Companion to Edgar Allan Poe (2002) seems to share this point of view when he states: "The narrator's inadvertent temporary burial of the cat along with his intentional burial of his wife's corpse may imply that the narrator has walled up, or, in psychological terms, repressed his feminine, nurturing elements in his psyche"92. This tale may thus show once again a desire to kill a part of one self. The narrator chooses to kill the first cat because he cannot stand his feminine traits. He succeeds in killing it but another cat appears, meaning that his feminine traits also re-appear because they cannot be dismissed. For the same reason, the narrator 
wants to murder the second cat. But when he tries to kill it, his wife intervenes and he ends up killing her instead. Because the violence is directed at her, the narrator reaffirms his masculinity, but only temporarily because when he tries to kill the second cat at the end of the tale, he fails. Moreover, because the narrator keeps his wife's corpse in a wall and because the cat reappears at the end, it is in fact a failed attempt to get rid of his feminine traits, probably highlighting an uncontrollable will to conserve this part of himself.

"Skin" also exposes this will to conserve something as the last method of abusing the body in the texts under consideration is to be found in the characters' choice of preserving their victims. As just explored, the narrator in "The Black Cat" indeed tries to repress his femininity by killing the cat and his wife. However, instead of getting rid of his wife's corpse, he decides to hide it: "I determined to wall it up in the cel1 ar" ${ }^{\prime \prime}$. The narrator nonetheless enumerates other possible ways of destroying his wife's corpse before proceeding to conceal it:

At one period I thought of cutting the corpse into minute fragments, and destroying them by fire. At another, I resolved to dig a grave for it in the floor of the cellar. Again, I deliberated about casting it in the well in the yard - about packing it in a box, as if merchandise, with the usual arrangements, and so getting a porter to take it from the house. ${ }^{94}$

Though it shows the narrator's awareness of other possible means to destroy the corpse, he still decides to keep it in his house and according to Fisher, it underlines the fact that even though he wants to eradicate his feminine traits, he cannot: "the live burial motif may deepen the narrator's repressed emotions, but such repression cannot be long sustained without leading to explosive reactions" 95 . By preserving his wife's corpse and the cat, the narrator shows that he is actually unable to steer clear of the feminine part of his self.

A battle between the feminine and the masculine is also a great concern in Dahl's "The Landlady" as the story presents a female character killing a male character and preserving his body. Billy Weaver, the young male protagonist of the story, is going to be killed by the mother figure he was desperate to have and that he finally found in the landlady. Jacques Sohier indeed refers to Billy's will to find a home and a mother to nurture him:

At the beginning of the short-story Billy Weaver is depicted as being desperate for a home fitted with all the qualities suggestive of snugness and pleasantness. He sees and makes an inventory of all the homely signs he can see in the landlady's living room. Being away from home, he yearns for the familiar place that a mother makes secure. ${ }^{96}$

The fact that the landlady looks like "the mother of one's best school-friend welcoming one into the house to stay for the Christmas holidays" ${ }^{\prime \prime 7}$ highlights Billy's desire for a nurturing woman who might replace his mother while he is away from home.

In the same way, the lady killer also wants something from Billy; according to Sohier: "What is expressed is a desire for the perfection of the skin, the fascination 
of the body, that could be associated with a desire for whiteness, the whiteness of teeth and, in the same breath, with an insistent apprehension of age and ageing, the whole compounded of a desire for a baby"98. To put it differently, the landlady may be looking for the son she has never had. Billy even assumes that "she had probably lost a son in the war, or something like that, and had never got over it" ${ }^{\prime 99}$. And this may be what drives her to keep her victim's body. Because she is looking for a child, and because she knew that Billy was not going to stay forever in her Bed \& Breakfast, she feels she has to kill him, and stuff him in order to have him by her side.

Dahl very much insists on her desire to keep her victim when describing his female character. For instance, when Billy arrives at the Bed \& Breakfast, he is full of stereotypes about that kind of place (that would eventually prove him right). He states that boarding houses remind him of "rapacious landladies" 100 . The adjective "rapacious" is relevant here because it suggests cupidity, or in other words, someone who does not want to share, who just wants to possess more. And this adjective does apply to the landlady in the story as she wants to possess her clients and, in order to do so, she kills and stuffs them. Moreover, a "rapace" is also a vulture, a bird of prey. The adjective is thus appropriate because the landlady is herself a killer and the clients are her preys. Later on, the landlady uses the word "nest" (12) to describe her house, equally highlighting this idea. Billy also assumes that boarding houses have a "powerful smell of kippers" ${ }^{101}$. A kipper is a fish that has been cut and gutted. Dahl thus repeatedly foreshadows Billy's fate and the landlady's sinister desire: like a kipper, Billy is about to be killed, opened up and disemboweled to be stuffed. The word "kipper" is also a homophone of the word "keeper" which may remind the reader of the landlady who accordingly wants to keep her victims' bodies.

Poe's "The Oval Portrait" and Dahl's "Skin" also deal with a desire to keep a body or more precisely, a pure image of a body. Indeed, in both stories, the young women are painted by someone who loves them. The artist in Poe's tale is the girl's husband: "And evil was the hour when she saw, and loved, and wedded the painter"102, and Soutine in Dahl's in story is clearly in love with his friend's wife as he keeps asking her if she "will marry [him]"103 and he accepts to tattoo his friend only because it is a portrait of Josie:

'All I am saying' the boy told him, 'is that you are drunk and this is a drunken idea.'

'We could have Josie for a model. A study of Josie upon my back. Am I not entitled to a picture of my wife upon my back?'

'Of Josie?'

'Yes.'

(...)

'A nude study,' the boy said. 'It's an agreeable idea'. ${ }^{104}$

The painters' desire to represent their muses is thus motivated by the love they have for them and for Art. Their will to portray these women may also be motivated by their will to preserve something that they know is going to expire: their beauty. In "The Oval Portrait", the young girl's "rarest beauty" 105 is underlined and in executing the portrait the artist has lost his bride, but he succeeded in creating an impression of her which will defy time; he has 
captured in his painting her most perfect beauty. In Dahl's short story, the way Soutine wants to paint Josie is quite relevant as it shows Soutine's desire for his muse: "Let her be standing there, by my dressing table. Let her brushing her hair. I will paint her with her hair down over her shoulders and her brushing it" ${ }^{106}$. This quote suggests that Josie has long hair that goes beyond her shoulders. And this striking image of the woman's hair is indeed a strong symbol because, as Anthony Synnott in "Shame and Glory: A Sociology of Hair" (1987); "long hair (...) has for centuries been both a gender sign and a sex symbol in our society" ${ }^{107}$. Soutine thus appears as being sexually driven to Jodie as his main focus when painting is on her hair and it underlines her sensuality. However, because the artist knows a body is not meant to last, he chooses to represent Jodie in a painting to defy time and keep a perfect image of her.

Bodies in pain abound in Poe's and Dahl's writing, whether they are being let to die, dismembered or killed and preserved. These tortured bodies, as this part just explored, may stand for an externalization of the characters' tortured minds. This mutilation of the body, because it is extensively developed in Poe and Dahl's work, may constitute what Charles Mauron calls a "métaphore obsédante" 108 and it may then compose the authors' "personal myth"109, highlighting the authors' own unconscious.

\section{Trauma Narratives?}

$\mathrm{V}$ incent Jouve, in La Poétique du Roman (1997) gives a very helpful and didactic synthesis of Mauron's method called psychocriticism by explaining the four stages of the analysis. The first stage consists in superimposing different texts from the same author in order to detect repetitive images that seem to obsess the author. The aim of the second stage of the method is to identify the "mythical figures and dramatic situations"110 that these images convey. The third stage must then enable a critical reader to uncover the author's personal myth and finally the last stage involves a confirmation of this information based on the author's biography. Therefore, according to Mauron, works of fiction are supposed to reflect an author's unconscious and psychocriticism is a useful tool to discover it. The different mutilations of the body in Poe and Dahl's work may thus be considered as "obsessive metaphors" as they are repeatedly dealt with in the stories under consideration and they stand for something else than their literal meaning. Poe and Dahl seem to share a similar "personal myth" as they both express the same obsessive images. Live burials, dismemberment and the conservation of bodies may indeed imply something else because those events are quite irrational as they are unlikely to happen.

Poe and Dahl's stories about live burials probably do not evoke the real fear of being buried alive but instead this motif becomes a symbol that may reveal their unconscious personality. It might indeed evoke a fear of confinement in general, or in other words, a feeling of claustrophobia. When read alongside the authors' biographies, the motif of live burials as a symbol of the authors' fear of confinement may indeed be validated. Poe's fear of confinement probably stems from his financial situation and his restricted professional career as a short story writer. According to many specialists, including Fisher; "Poe's 
major demon, so to speak was poverty. More than any other cause, hardships and worries regarding scanty financial means troubled Poe's life"111. The publication of his first volume of poetry brought him no money and that is one of the reasons why he enlisted in the army and then, decided to write Gothic fiction. As Hammond explains:

Throughout his literary career Poe regarded himself as first and foremost a poet and only secondarily a writer of short stories. He had turned to the writing of fiction when he realised that his earnings from poetry would be insufficient for his modest needs, but in the last analysis he felt this was a distraction from his central artistic concerns. ${ }^{112}$

Poe's little financial reward led him to write Gothic fiction because he knew this genre was flourishing and could, financially speaking, be helpful. Poe's desperate financial situation thus persuaded him to write fiction that would sell in popular magazines instead of writing poetry, which really was his passion. Because Poe could not support his family just by writing poetry, he had to write fiction and may have felt imprisoned in a role of short story writer.

Roald Dahl's fear of confinement may also be found when reading the author's biography. As Donald Sturrock reveals; the author's schooldays were dreadful and his "pleasures of youth had been stifled by an unfair system that was devoid of affection and feeling ... " 113 . Dahl was bullied at school: he was beaten and tortured by older boys and his teachers were also violent to him. Indeed, in his autobiography entitled Boy: Tales of Childhood, Dahl describes his childhood and, more specifically, his violent schooldays: "All through my school life, I was appalled by the fact that masters and senior boys were allowed literally to wound other boys, and sometimes quite severely"114. Accordingly, Dahl's feeling of claustrophobia may come from his schooldays because he felt he could not escape the tortures and his tormentors (even though he tried many times). And that is probably one of the reasons why he wrote short stories about bullied women who take their revenge. The motif of live burials in Poe and Dahl's work thus works as an obsessive metaphor and it may represent the authors' fear of not being free.

The recurrent images of dismemberment in Poe and Dahl's stories may also be an obsessive metaphor. The motif of dismemberment may be linked to the fear of castration because, in both cases, the body is sliced into pieces. According to the online Centre National de Ressources Textuelles et Lexicales, the word "castration" refers to an operation aiming at removing the testicles or the ovaries of an individual in order to prevent him or her from reproduction ${ }^{115}$. However, in Poe and Dahl's fiction, this fear of castration does not have to be a literal fear of castration.

Metaphorically, as the Collins Concise Dictionary highlights, a man can be castrated by losing his "vigour and masculinity"116 and the recurrent image of dismemberment in Poe and Dahl's stories may indeed represent the fear of losing one's manhood. As previously dealt with, Poe's fear of losing his masculinity may come from his chaotic financial situation because he was the breadwinner of his family and he may have felt like he could not financially 
support his wife. In Fathers in Victorian Fiction (2011), Natalie McKnight quotes Trev Lynn Broughton and Helen Rogers' Gender and Fatherhood in the Nineteenth Century: "men's primary identity became associated with the shop, the office or the factory, and with the role of provider,"leaving women with more responsibilities on the domestic front (Broughton and Rogers 2007, 6-7)"117. Moreover, as Hammond underlines: "There has been much speculation by biographers regarding the relationship between Poe and his child-wife. That he was deeply devoted towards her there can be no doubt, but controversy persists as to whether he regarded her as a dearly-loved sister or as a wife in the conventional sense"118. To put it differently, Poe's marriage has been regarded by many biographers as a chaste one, especially by Joseph Wood Krutch who insisted that "Poe and Virginia did not have a normal married life and that 'prolonged illness made sexual relations with her impossible after she reached maturity"'119. Poe's unconsummated marriage thus reinforces the motif of dismemberment as a symbol representing his fear of castration, his fear of not being manly enough.

As far as Dahl is concerned, the motif of dismembering a body may also symbolize his fear of castration. The fact that the author was constantly humiliated and tortured by his schoolmates and teachers may have developed his fear of castration as he was not in a manly position and did not dare to confront his troublemakers to stand his ground. Moreover, as a child, Roald Dahl witnessed many deaths that could have played a role in the author's fear of losing his manhood. Indeed, his father, Harald, died when Dahl was only three years old and his mother, Alfhild, had to struggle to support her family. Dahl's father died and could not assume his role, probably leaving Roald Dahl with a desire to do what his father could not: protect his family. Growing up without a father figure may indeed have affected Dahl because, according to David B. Lynn who wrote an article entitled "The Husband-Father Role in the Family" (1961), a child, and especially a boy, needs a father in order to learn how to be a man: "The presence of the father seems especially important in the development of boys. The man of the house is the model of the boy's future potential as a man. The boy in effect says of his father, 'So that is what it is like to be a man" ${ }^{120}$. Because of his father's death, Dahl probably became unconsciously afraid of losing his own masculinity, just like the male characters of his stories whose powers are destroyed after their death. For instance, William in "William and Mary" is, at the end, considered as a child by his wife, who eventually takes the power back: “'He's like a baby, that's what he's like. He's exactly like a little baby"'121. This comparison to a baby obviously undermines and even kills William's masculinity and it may reflect Dahl's own unconscious fear of castration ${ }^{122}$. The name "Pearl" also suggests this undermining as it may imply a piece of jewelry (which is generally worn by women) and it can thus foreshadow William's fate because, after the surgery, he will be his wife's object. Therefore, according to Charles Mauron's theory, the recurrent images of a body being dismembered in the short stories under consideration can be considered as obsessive metaphors, expressing the authors' unconscious fear of being emasculated.

The last method of mutilating the body in Poe and Dahl's tales, that is to say the conservation of the body, can also be considered 
as an obsessive metaphor and it may express the authors' fear of losing something, and more precisely someone they care about. Both authors' lives were indeed fraught with personal dramas. Poe and Dahl were surrounded by death and this fear of losing someone may thus stem from the painful experiences they had to face. As it is generally known, Poe "lost an unusual number of beautiful, relatively young, nurturing females in his lifetime: his mother, Eliza Poe; his foster mother, Fanny Allan; the mother of one of his friends, Jane Stanard and his own wife, Virginia Clemm"123. As a child, Roald Dahl also witnessed many deaths in his family: in 1920, his seven year old sister, Astri, "died from [an] infection [after she] was diagnosed with acute appendicitis" ${ }^{\prime 24}$ and his father died the same year. Because the authors encountered death very early in their lives, they may have been afraid of losing another loved one or being all by themselves. Unconsciously, these fears of loss and solitude found their way into their fiction, and more precisely in the obsessive metaphor of preserving a body. Because Poe and Dahl's fiction are filled with many obsessive metaphors that reflect their personal myth and their unconscious personality, their stories may nowadays be considered as "trauma narratives".

\section{Conclusion}

E dgar Allan Poe found serious followers in fiction in the twentieth century who "began to revive the Gothic heritage in line with the findings of contemporary psychology, psychiatry and psychoanalysis" 125 and Roald Dahl was undoubtedly one of them. As this paper tried to highlight, both authors share many similarities in their short fiction. Poe's name is inextricably entwined with literary Gothicism and most of Dahl's short stories derive from this Gothic tradition. Moreover, both authors, by representing many mutilated bodies in their tales, seem to be fascinated by the special relationship a body has with the mind. Buried, dismembered or killed and conserved bodies abound in Poe's and Dahl's fiction and these mutilated bodies may stand for an externalization of the characters' unbalanced minds because they are going through an identity crisis and long to express themselves.

From a psychocritical point of view, because it is a repetitious motif in Poe and Dahl's work, this mutilation of the body 'may constitute an "obsessive metaphor" and may represent the authors' "personal myth". Live burials, dismemberments and the conservation of the body are thus obsessive metaphors that may echo the authors' unconscious, and more precisely their fears of confinement, castration and loss. Indeed, when confronted to the authors' biography, this assumption may be validated because their lives were fraught with personal traumas from which their fears may have come. Mauron's psychocriticism may therefore be considered as a precursor of literary trauma theory, a theory which can also be applied to Poe and Dahl's fiction. Both theories express the idea that an author's life can be transferred into his fiction and unconsciously represented in a literary work. 


\section{BibLIOGRAPHY}

\section{PRIMARY SOURCES}

Roald Dahl, Bizarre! Bizarre!,1959, Paris, Gallimard, 1962.

---, Boy: Tales of Childhood, 1984, New-York, Puffin Books, 2013.

---, Coup de Chance et Autres Nouvelles, 1977, Paris, Gallimard, 2009.

---, Kiss Kiss, 1959, London, Penguin books, 1962.

Edgar Allan Poe, Complete Tales and Poems, New York, Vintage Books, 1975.

---, Essays and Reviews, New-York, Literary Classics of the United States, 1984.

\section{SECONDARY SOURCES}

Ailsa Cox and Christine Lorre-Johnston, The Mind's Eye: Alice Munro's Dance of the Happy Shades, Paris, Fahrenheit Books, 2015.

Andrew Mangham, "Buried Alive: The Gothic Awakening of Taphephobia”, Journal of Literature and Science, Volume 3, No. 1, pp. 10-22, 2010.

Ann Alston and Catherine Butler (eds), Roald Dabl, Basingstoke, Palgrave Macmillan, 2012.

Anthony Synnott, „Shame and Glory: A Sociology of Hair“, The British Journal of Sociology, Vol. 38, No.3, pp. 381-413, London, Wiley on behalf of The London School of Economics and Political Science, 1987

Benjamin F. Fisher, The Cambridge Introduction to Edgar Allan Poe, Cambridge, University Press, 2008. Bernard Brugière, Les figures du corps dans la littérature et la peinture anglaises et américaines de la Renaissance à nos jours, Paris, Publications de la Sorbonne, 1991.

"Castrate", Collins Concise Dictionary, $5^{\text {th }}$ edition, Glasgow, HarperCollins Publishers, 2001.

"Castration", Centre National de Ressources Textuelles et Lexicales, 2012.

Charles Mauron, Des Métaphores Obsédantes au Mythe Personnel: Introduction à la Psychocritique, Paris, Librairie José Corti, 1962.

David B. Lynn, "The Husband-Father Role in the Family", Marriage and Family Living, Vol. 23, No. 3, pp. 295-296, Minneapolis, National Council on Family Relations, 1961.

David Halliburton, Edgar Allan Poe: A Phenomenological View, Princeton, Princeton University Press, 1973.

"Dismember", The Free Dictionary Online by Farlex, 2016.

Donald Sturrock, Storyteller - The Life of Roald Dabl, London, Harper Press, 2010.

Fred Botting, Gothic, London, Routledge, 1996.

Frederick S. Frank, Through The Pale Door: A Guide to and Through the American Gotbic, New York, Greenwood Press, 1990.

Graham Clarke, Edgar Allan Poe: Critical Assessments, Volume I, Mountfield, Helm Information Ltd, 1991.

---, Edgar Allan Poe: Critical Assessments, Volume II, Mountfield, Helm Information Ltd, 1991.

---, Edgar Allan Poe: Critical Assessments, Volume III, Mountfield, Helm Information Ltd, 1991.

---, Edgar Allan Poe: Critical Assessments, Volume IV, Mountfield, Helm Information Ltd, 1991.

Jacques Sohier, "Metamorphoses of the Uncanny in the Short-Story "The Landlady" by Roald Dahl", Miranda Revues Online, 29 Nov 2011.

Jean-François Mattéi, Le Sens de la Démesure: Hubris et Dikè, Cabris, Sulliver, 2009.

Jeffrey Meyers, Edgar Allan Poe: His Life and Legacy, New-York, Cooper Square Press, 2010.

Jeremy Treglown, Roald Dahl: a Biography, New York, First Harvest Edition, 1995.

John Mullan, "The Origins of the Gothic, Discovering Literature: Romantics And Victorians",

British Library Online.

JR Hammond, An Edgar Allan Poe Companion, London, The Macmillan Press Ltd, 1981. 
Kevin J. Hayes (ed), The Cambridge Companion to Edgar Allan Poe, Cambridge, Cambridge University Press, 2002.

Lorna Piatti-Farnell, "A Tour of the Cannibal Quarters: Industrial Fantasies and Carnivorous Appetites in Roald Dahl's Fiction”, Otherness: Essays and Studies, 2010.

Marie Bonaparte, Edgar Poe: Sa Vie, Son Oeuvre: Etudes Analytique, 1933, Paris, Presses Universitaires de France, 1958.

Marie Mulvey-Roberts, (ed), The Handbook to Gothic Literature. Basingstoke, MacMillan, 1998.

Mystery Writers of America, 2016.

Natalie McKnight (ed), Fathers in Victorian Fiction, Cambridge Scholars Publishing, 2011.

Robert Shulman, „Poe and The Powers of the Mind“, ELH, Vol. 37, No. 2, pp. 245-262, Baltimore, The Johns Hopkins University Press, 1970.

Sigmund Freud, L'Inquiétant Familier, Paris, Editions Payot \& Rivages, 2011.

Vincent Jouve, La Lecture, Paris, Hachette Livres, 1993.

---. Poétique du Roman, Troisième Edition, Paris, Armand Colin, 2010.

\section{Notes}

1. Jacques Sohier, "Metamorphoses of the Uncanny in the Short-Story ,The Landlady' by Roald Dahl", in Miranda Revues Online, 2011, p. 4.

2. Each year, since 1945, this organization has presented „The Edgar Awards“ which aim at „promoting higher regard for crime writing and recognition and respect for those who write within the genre“. (https://mysterywriters.org/about-mwa/mwa-history/).

3. Donald Sturrock, Storyteller - The Life of Roald Dabl, London, HarperPress, 2010, p. 5.

4. Ibid., p. 56.

5. Lorna Piatti-Farnell, „A Tour of the Cannibal Quarters: Industrial Fantasies and Carnivorous Appetites in Roald Dahl's Fiction“, in Otherness: Essays and Studies, 2010, p. 1.

6. Marie Mulvey-Roberts (ed), The Handbook to Gotbic Literature, Basingstoke, MacMillan, 1998, p. 38.

7. My translation of „L'aspect le plus connu de la représentation du corps chez Poe [est] le corps mis en pièces, le corps-machine des cartésiens démonté jusqu'au dernier boulon" in Bernard Brugière. Les figures du corps dans la littérature et la peinture anglaises et américaines de la Renaissance à nos jours, Paris, Publications de la Sorbonne, 1991, p. 238.

8. Ailsa Cox et Christine Lorre-Johnston, The Mind's Eye: Alice Munro's Dance of the Happy Shades, Paris, Fahrenheit Books, 2015, p. 29.

9. My translation of "Poser 'le corps', c'est supposer 'ce qui ne serait pas le corps' » in Brugière, Les figures du corps, p. 237.

10. https://www.bl.uk/romantics-and-victorians/articles/the-origins-of-the-gothic.

11. Edgar Allan Poe, Complete Tales and Poems, New York, Vintage Books, 1975, p. 290.

12. Ibid., p. 290.

13. Ibid., p. 290.

14. Ibid., p. 290.

15. Ibid., p. 275.

16. Ibid., p. 275.

17. Frederick S. Frank, Through The Pale Door: A Guide to and Through the American Gothic, New-York, Greenwood Press, 1990, p. 208.

18. Cox and Lorre-Johnston, The Mind's eye, p. 29.

19. Roald Dahl, Kiss Kiss, 1959, London, Penguin books, 1962, p. 48.

20. Ibid., p. 48.

21. Ibid., p. 22.

22. Ibid., p. 59. 
23. Mulvey-Roberts (ed), The Handbook to Gothic Literature, p. xvi.

24. Jeremy Treglown, Roald Dabl: a Biography, New York, First Harvest Edition, 1995, p. 121.

25. Dahl, Kiss Kiss, p.121.

26. Cox and Lorre-Johnston, The Mind's eye, p. 32.

27. Sigmund, Freud, L'Inquiétant Familier, Paris, Editions Payot \& Rivages, 2011, pp. 29-30.

28. Dahl, Kiss Kiss, p.10.

29. Ibid., p.11.

30. Sohier, « Metamorphoses », p. 4.

31. Dahl, Kiss Kiss, pp.42-43.

32. Poe, Complete Tales and Poems, p. 303.

33. Dahl, Kiss Kiss, p. 20.

34. Dahl, Kiss Kiss, pp. 20-21.

35. Poe, Complete Tales and Poems, p. 227.

36. Ibid., p. 223.

37. Ibid., p. 224.

38. Sohier, « Metamorphoses ", p. 3.

39. Dahl, Kiss Kiss, p. 17.

40. Poe, Complete Tales and Poems, p.133.

41. Ibid., p. 291.

42. Ibid., p. 290.

43. Sturrock, Storyteller, p. 301.

44. My translation of „Tout ce qui est lié à la mort, aux cadavres et au retour des morts, des esprits et des spectres parait hautement inquiétant à beaucoup de personnes" in Freud, L'inquiétant Familier, p. 68.

45. Mulvey-Roberts (ed), The Handbook to Gothic Literature p. 123.

46. Ibid., p. 40.

47. Benjamin. F, Fisher, The Cambridge Introduction to Edgar Allan Poe, Cambridge, University Press, 2008, p. 24.

48. Sturrock, Storyteller, p. 275.

49. Fisher, The Cambridge Introduction to Edgar Allan Poe, pp. 22-23.

50. Quoted in Andrew Mangham, "Buried Alive: The Gothic Awakening of Taphephobia", Journal of Literature and Science, Volume 3, No. 1, pp. 10-22. 2010, p. 10.

51. Poe, Complete Tales and Poems, p. 274.

52. Ibid., p. 276.

53. JR, Hammond, An Edgar Allan Poe Companion, London, The Macmillan Press Ltd, 1981, p. 89.

54. Poe, Complete Tales and Poems, p. 274.

55. Dahl, Kiss Kiss, p. 47.

56. Ibid., p. 47.

57. Ibid., p. 48.

58. Mulvey-Roberts (ed), The Handbook to Gothic Literature, p. 115.

59. Dahl, Kiss Kiss, p. 47.

60. David, Halliburton, Edgar Allan Poe: A Phenomenological View, Princeton, University Press, 1973, p. 347.

61. Hammond, An Edgar Allan Poe Companion, p. 89.

62. http://www.thefreedictionary.com/dismembered.

63. Poe, Complete Tales and Poems, p. 305.

64. Dahl, Kiss Kiss, p. 28.

65. Ibid., p. 28.

66. Poe, Complete Tales and Poems, p. 224.

67. Graham, Clarke, Edgar Allan Poe: Critical Assessments, Volume I, Mountfield, Helm Information Ltd, 1991, pp. 66-67.

68. Halliburton, Edgar Allan Poe: A Phenomenological View, p. 337. 
69. Dahl, Kiss Kiss, p. 19-20.

70. Ibid., p. 20.

71. Ibid., p. 20.

72. Ibid., p. 20.

73. Ibid., p. 19.

74. Ibid., p. 22.

75. Ibid., p. 23.

76. Ibid., p. 23.

77. Ibid., p. 25.

78. Ibid., p. 37.

79. My translation of "passion violente d'orgueil qui témoigne plus fondamentalement d'un refus de la condition humaine en niant la limite qui sépare les mortels des immortels" in Jean-François, Mattéi, $L e$ Sens de la Démesure: Hubris et Dikè. Cabris: Sulliver, 2009, p. 28.

80. Dahl, Kiss Kiss, p. 38.

81. Ibid., p. 38.

82. Ibid., p. 23.

83. Ibid., p. 24.

84. Graham Clarke, Edgar Allan Poe: Critical Assessment, Volume III, Mountfield, Helm Information Ltd, 1991, p. 68.

85. Dahl, Kiss Kiss, p. 27.

86. My translation of "[...] le chat est un symbole classique de l'organe génital féminin [...] Le chat a d'ailleurs réellement en commun avec l'organe féminin le poil fourni, chaud, voluptueux et irritant au toucher: la femme a un chat là-même où l'homme a un pénis; de plus toute l'allure du petit félin est féminine par la grâce et même par la traîtrise de ses mouvements, où la griffe est toujours prête à sourdre de la patte de velours" in Marie, Bonaparte, Edgar Poe: Sa Vie, Son Oeuvre: Etudes Analytique, Paris, Presses Universitaires de France, 1958, p. 561.

87. Robert Shulman, „Poe and The Powers of the Mind“, ELH. Vol. 37, No. 2, p. 257.

88. Poe, Complete Tales and Poems, p. 224.

89. Ibid., p. 224.

90. Ibid., p. 223.

91. Ibid., p. 223.

92. Kevin J. Hayes (ed), The Cambridge Companion to Edgar Allan Poe, Cambridge University Press, 2002, p. 86.

93. Poe, Complete Tales and Poems, p. 228.

94. Ibid., p. 228.

95. Fisher, The Cambridge Introduction to Edgar Allan Poe, p. 86.

96. Sohier, « Metamorphoses », p. 7.

97. Dahl, Kiss Kiss, p. 12.

98. Sohier, « Metamorphoses », p. 8.

99. Dahl, Kiss Kiss, p. 13-14.

100. Ibid., p. 10.

101. Ibid., p. 10.

102. Poe, Complete Tales and Poems, p. 291.

103. Dahl, Kiss Kiss, p. 123 and 126.

104. Ibid., p. 128-129.

105. Poe, Complete Tales and Poems, p. 291.

106. Dahl, Kiss Kiss, p. 131.

107. Anthony Synott, „Shame and Glory: A Sociology of Hair“. The British Journal of Sociology. Vol.38, No.3, pp. 381-413, London: Wiley on behalf of The London School of Economics and Political Science, 1987, p. 384. 
108. Charles Mauron, Des Métaphores Obsédantes au Mythe Personnel: Introduction à la Psychocritique, Paris, Librairie José Corti, 1962, p. 9.

109. Ibid., p. 9.

110. Vincent Jouve, La poétique du Roman, Troisième Edition, Paris, Armand Colin, 2010, p. 125.

111. Fisher, The Cambridge Introduction to Edgar Allan Poe, p. 4.

112. Hammond, An Edgar Allan Poe Companion, p. 151.

113. Sturrock, Storyteller, p. 70.

114. Roald Dahl, Boy: Tales of Childhood, New-York, Puffin Books, 2013, p. 183.

115. „Opération ayant pour but ou résultat de priver l'individu mâle ou femelle de ses facultés de reproduction" (http://www.cnrtl.fr/definition/castration).

116. “Castrate”, Collins Concise Dictionary, $5^{\text {th }}$ edition, Glasgow, HarperCollins Publishers, 2001, p 254. 117. Natalie McKnight (ed), Fathers in Victorian Fiction, Cambridge Scholars Publishing, 2011, pp. 1-2. 118. Hammond, An Edgar Allan Poe Companion, p. 19.

119. Quoted in Meyers, Jeffrey, Edgar Allan Poe: His Life and Legacy, New-York, Cooper Square Press, 2010, p. 86.

120. David B. Lynn, "The Husband-Father Role in the Family", Marriage and Family Living, Vol. 23, No. 3, pp. 295-296, Minneapolis, National Council on Family Relations, 1961, p. 296.

121. Dahl, Kiss Kiss, p. 43.

122. Dahl's fear of castration is also made extremely explicit in one of his other short stories entitled "Georgie Porgy". Indeed, in the story, a sexually repressed vicar is seduced by a woman who eventually swallows him whole.

123. Hayes, The Cambridge Companion to Edgar Allan Poe, p. 149.

124. Sturrock, Storyteller, p. 37.

125. Mulvey-Roberts (ed), The Handbook to Gothic Literature, p. 155. 